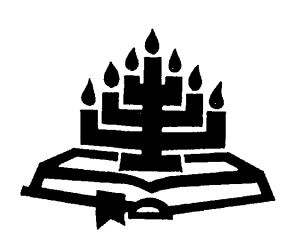

\title{
Pastorale sorg aan gemarginaliseerdes met spesifieke verwysing na kinderhuiskinders
}

\author{
D. Maree
}

Uitvoerende Voorsitter, Overstrand Kinder- en Jeugsorgsentrum BETTIESBAAI

E-pos: deon@kerk.co.za

J. Janse van Rensburg

Departement Praktiese Teologie

Universiteit van die Vrystaat

BLOEMFONTEIN

E-pos: jjvanr@yebo.co.za

\section{Abstract \\ Pastoral care to the marginalized with special reference to orphanaged children}

The plight of the marginalised was the point of departure for this research, with special emphasis on orphan boys. The specific circumstances under which the child was removed from his negative circumstances, his past, his adoption in the children's home and the special needs and problems he has in the children's home are explored. In this article, Biblical principles for the care of orphanaged children were generated and specific attention was given to God's emphasis on and passion for the marginalised - with special reference to orphanaged children. Attention is given to the Biblical mandate, responsibility and command to the church to be involved in the lives of orphanaged children. Conclusions are derived from the literature study as well as from a limited phenomenological study which was done through analyses of questionnaires designed to address the research hypotheses. It is hoped that reasons for the lack of interest in and involvement with orphanaged children will be revealed. 


\section{Opsomming}

\section{Pastorale sorg aan gemarginaliseerdes met spesifieke verwysing na kinderhuiskinders}

Die uitgangspunt van hierdie artikel is die stryd van gemarginaliseerdes met spesifieke verwysing na seuns in die kinderhuis. Ondersoek is gedoen na die spesifieke omstandighede waaronder kinders uit hulle ouerhuise verwyder is, hulle geskiedenis, hulle opname en aanpassing in die kinderhuis. Bybelse beginsels vir die versorging van gemarginaliseerde (dus ook kinderhuiskinders) word aangedui terwyl aandag geskenk word aan God se spesiale sorg vir gemarginaliseerdes. Aandag is ook gegee aan die Bybelse mandaat, opdrag en verantwoordelikheid van die kerk om by die lewens en sorg van kinderhuiskinders betrokke te wees. Gevolgtrekkings wat uit die beskikbare literatuur gemaak is, is aangevul met 'n beperkte fenomenologiese waarneming wat deur middel van 'n vraelys gefasiliteer is. Die vraelys is na aanleiding van die probleemstelling en hipoteses geformuleer en die verwagting is geskep dat die gebrek aan betrokkenheid van lidmate en predikante by die lewens van kinders in die kinderhuis sowel as by die kinderhuis se werksaamhede, hiermee blootgelê kan word.

\section{Inleiding}

Armoede, kinderverwaarlosing, VIGS en die misbruik van afhanklikheidsvormende middels veroorsaak dat kinders van hierdie geslag, soos waarskynlik nog nooit vantevore nie, die risiko loop om in 'n kinderhuis te beland. Cattanach (2003:121) som die dilemma soos volg op:

We claim to be a child-centred society, but in reality there is little evidence that we are. In many ways we are a ruthlessly adult-centred society where children are defined almost exclusively in terms of their impact on adult lives. Our adult-centred society has tried to contain and limit the impact of children on adult life by either excluding them from much of it, or blaming them for disturbing it.

Weinig literatuur gee aandag aan die pastorale versorging van gemarginaliseerdes - spesifiek die kinderhuiskinders. Hoe behoort die pastor in die besonder en Christene in die algemeen die kinderhuiskind te ondersteun en te versorg? Waar terapeutiese beraad benodig word, moet die Skrifbeginsel van Matteus 25:31-46 uitgeleef word. Tóg is daar onkunde oor hoe dit benader behoort te word. 


\section{Probleemstelling}

Vanaf die vroegste tye, was daar in enige samelewing armes en verstotenes. Hulle ervaar dat hulle deur die gemeenskap gemarginaliseer word. Hierdie term dui in die algemeen op diegene wat met karige klere moet klaarkom, honger of siek is, hulleself in die gevangenis bevind, vereensames, weduwees, vreemdelinge en fisiek gestremdes. Dit is hulle van wie die Meester getuig dat deur hulle te versorg, ons Hom eer (Matt. 25:31-46). Tóg blyk dit dat daar min betrokkenheid van die gemeenskap en spesifiek die lidmate van gemeentes by sulke gemarginaliseerdes is. As dit so 'n streng opdrag van Jesus Christus was, waarom neem so min gelowiges dit ernstig op? Hoe behoort hierdie betrokkenheid te wees? Wat kan meer gedoen word as om bloot geld en goedere te gee?

\section{Hipoteses}

Die navorsing word deur die volgende hipoteses gerig:

- Christene is nie op 'n geestelike vlak in die lewens van kinderhuiskinders betrokke nie.

- 'n Gebrek aan inligting is waarskynlik 'n belangrike rede vir lidmate se onbetrokkenheid by kinderhuiskinders.

- Christene ontvang nie genoegsame leiding en gestruktureerde geleenthede om in die lewens van kinderhuiskinders betrokke te wees nie.

- Vooroordele teenoor kinderhuiskinders veroorsaak dat Christene nie in die lewens van kinderhuiskinders betrokke wil wees nie.

- Christene is huiwerig om in die vorm van interpersoonlike verhoudings in die lewens van kinderhuiskinders betrokke te wees.

\section{Doel van die studie}

Die doel van hierdie studie is om die gestelde hipoteses te toets. Inligting wat vanuit die fokusgroepe en literatuurstudie bekom word, dien as merkers om strategiese riglyne te ontwikkel wat deur die pastor en ander Christene gebruik kan word in hulle kontak en verhoudings met kinderhuiskinders ten einde by die kinders groter singewing in hulle lewe te fasiliteer en om die wil van God vir hulle lewens te ontdek. 


\section{Navorsingsmetode en -prosedure}

Vir die samestelling van die literatuurstudie het die navorsing gebruik gemaak van bronne binne en buite die vakgebied van Praktiese Teologie. Vakartikels sowel as bronne vanuit die menswetenskappe is geraadpleeg. Voorts is die internet ook as inligtingsbron gebruik. Die dataversameling is teen die agtergrond van die gestelde hipoteses en doelwitte geïnterpreteer.

'n Kwalitatiewe ondersoek wat uit fokusgroeponderhoude bestaan, is ook in die metodologie ingesluit. Dit sluit aan by Schurink et al. (1998:313) se uitgangspunte vir 'n kwalitatiewe studie. Kennis is ook geneem van Babbie en Mouton (2001:33) se omskrywing van fenomenologiese navorsing, naamlik:

For the phenomenologist and other similar viewpoints (hermeneutics, symbolic interactionism, ethnomethodology) the aim of social sciences is primarily directed towards the understanding of individuals in terms of their own interpretations of reality and understanding of society in terms of the meanings which people ascribe to the social practices of society.

Met die fokusgroepmetode van data-insameling is die doel juis om deur middel van die "understanding of society in terms of the meanings which people ascribe to the social practices of society" inligting te verkry. Stanford (2003:3) konstateer dat fenomenologie die letterlike bestudering van 'n persoon is wat poog om sy eie ervarings van die werklikheid en die fenomeen wat bestudeer word, op 'n interpretatiewe manier weer te gee.

\section{Semantiese perspektief}

\subsection{Statutêre definisie van 'n kinderhuiskind}

In die huidige konteks van die wetgewing en omstandighede in SuidAfrika verwys 'n kinderhuiskind na 'n kind wat deur 'n maatskaplike werker sorgbehoewend bevind is. Met die gebruik van statutêre maatreëls en/of kinderhofprosedure is sodanige kind gevolglik uit sy/haar omstandighede, wat die ouerhuis kan beteken, verwyder en in die sorg van 'n staatsgoedgekeurde instansie soos 'n geregistreerde kinderhuis geplaas.

Verskeie disfunksionele gesinsomstandighede is dikwels die rede vir die kind se verwydering uit sy ouers se sorg en sy opname in 'n kinderhuis (Nicholas et al., 2003:78; Steenberg, 1995:33). Geestesongesteldhede by die ouers, huweliksgeweld en ouers wat in die 
tronk is, is soms ook bydraende faktore tot die institusionalisering van die kinders (Nicholas et al., 2003:78).

\subsubsection{Faktore wat bydra tot die verwydering van 'n kind}

'n Kind word gewoonlik uit sy ouers se sorg verwyder wanneer die ouers op grond van die Wet op Kindersorg (Suid-Afrika, 1983: Artikel 14(4)) onbevoeg bevind word om hulle kinders te versorg (Bosman-Swanepoel \& Wessels, 1995:39-40). Dit geld wanneer die gedrag van die ouers van so 'n aard is dat dit nadelig op die kind inwerk, soos beskryf in Artikel 14(4) (Suid-Afrika, 1983) of wanneer die ouer byvoorbeeld die kind ontneem van aspekte wat belangrik is vir sy normale ontwikkeling (Toerien, 2001:27).

Kinders wat in ' $n$ kinderhuis geplaas word as gevolg van een of ander bepaling van die wet, ondervind en ervaar nie noodwendig dat hierdie verwydering goed is nie (Paul, 1993:28). Alhoewel daar gepoog word om deur die wet die kind te beskerm, vind emosionele, sosiale en geestelike skade steeds plaas as gevolg van die verwydering. Die kind ervaar ook nie altyd die omstandighede waaruit hy/sy verwyder word as negatief nie (Van der Lith, 1999:23). Die kind besef en weet nie dat die omstandighede waarin hy/sy verkeer 'n negatiewe invloed op hom/haar het nie. Die omstandighede word dus gelate aanvaar, omdat hy/sy nie van beter weet nie. Die navorser se ervaring is dat daar min gevalle is waar die ouers hulle omstandighede sodanig verbeter het dat die kind sondermeer in die ouers se sorg teruggeplaas kan word.

\subsubsection{Gevoelens en gedrag tydens verwydering}

Tydens die kind se verwydering kom die volgende gedrag en gevoelens na vore:

- Ander mense, behalwe sy/haar gesin, word vir die verwydering blameer.

- Alle volwassenes word as vyandig beskou.

- Rebelse gedrag word getoon.

- Gevoelens wissel van verligting, vrees vir die onbekende, ongelukkigheid en hartseer.

- Gevoelens van eensaamheid en magteloosheid kom voor.

- Die kind voel dat niemand hom/haar wil hê nie. 
- Die kind staan negatief teenoor hom-/haarself.

- Die kind weier om foute te erken.

- Ander - veral volwassenes - word gewantrou.

- Die kind is impulsief, aggressief, teruggetrokke, belangeloos, hiperaktief of selfdestruktief (Roberts, 1990:35, 36).

Om die kinderhuiskind werklik te verstaan, moet aandag geskenk word aan die kind se belewing van sy/haar verwydering, asook aan die rol van die gebrek aan behoeftebevrediging (Toerien, 2001:26.)

Die omstandighede en gesinsopset wat die kind voor die verwydering beleef het, is alreeds traumaties en word dan gevolg deur 'n verdere trauma, naamlik die verwyderingsproses en die aanpassing in die kinderhuis (Van der Merwe, 2002:18).

\subsection{Breër betekenis van die begrip kinderhuiskind}

'n Kinderhuiskind is in die breër sin van die woord ook wees en "fatherless". Die ouer(s) of voog(de) het die kind in só 'n posisie van verwaarlosing en magteloosheid agtergelaat dat hy/sy in werklikheid wees en "fatherless" is. Dit bring mee dat sodanige kind wesenlik arm en wees is, met dieselfde status as 'n weduwee en vreemdeling. Die afleiding word gevolglik gemaak dat 'n kinderhuiskind ' $n$ "gemarginaliseerde" genoem kan word en verder ook dat indien daar van die behoeftige situasie van ' $n$ "arm mens" gepraat word, dit ook die situasie van 'n "wees-/kinderhuiskind" insluit.

Teen die agtergrond van die kerk se roeping in die wêreld (Janse van Rensburg, 2000:5) is die versorging van kinderhuiskinders, as een spesifieke groep gemarginaliseerdes, fundamenteel tot die lewe van die kerk. Daarom behoort gelowiges aktief betrokke te wees by die soeke na beginsels en praktyke wat die lot van kinderhuiskinders kan verander.

\subsection{Bybelse perspektief}

Die begrip gemarginaliseerd word waarskynlik die beste beskryf deur die woorde "arm, wees, weduwee en vreemdeling" soos dit in die Bybel voorkom. Die gemene deler van al hierdie begrippe kom na vore wanneer God se medelye met al hierdie groepe bestudeer word. 
Die woord armoede kom in 'n verskeidenheid betekenisse en toepassings in sowel die Ou as die Nuwe Testament voor. Sonder om in detail daarop in te gaan, kom die woord in vyf verskillende vorms in Hebreeus voor, terwyl daar twee betekenisse in die Griekse Nuwe Testament voorkom. Die omvang, impak en volle kontekstuele betekenis van hierdie woorde, tesame met die woorde "wees, weduwee en vreemdeling" kom in verskillende Afrikaanse woordeboeke voor en sou onder andere as volg omskryf kan word: verlatenheid, onderdruk, sonder verweer, vernederd, in nood, swak, afhanklik, hulpeloos, sosiaal minderwaardig met 'n lae selfbeeld, 'n bedelaar, ensovoorts. Aangesien daar reeds drie verskillende woorde vir hierdie spesifieke groep gemarginaliseerdes gebruik word, vereis dit verdere en meer gedetailleerde verduidelikings:

- Weeskind: In die eng sin van die woord verwys 'n weeskind na 'n kind waarvan albei ouers nie meer leef nie en wat gevolglik wees agtergelaat is.

- Fatherless: Dit is 'n Bybelse term wat daarop dui dat die vader van 'n kind nie meer leef nie. 'n Pa in die Ou-Testamentiese tyd het ' $n$ baie belangrike rol in die welstand, status en toekoms van 'n gesin vervul. Die pa was die enigste broodwinner, die enigste toegang vir die gesin tot regspraak, om op die mark handel te dryf, ensovoorts. Die status en sekuriteit van die gesin was in die pa gesetel. Die ma het 'n minder belangrike rol in hierdie opsig vertolk. Dit is dus nie vreemd dat die magtelose posisie van ekonomiesbenadeelde en sonder behoorlike toegang tot die reg, 'n kind as fatherless beskryf nie.

- Kinderhuiskind: Die begrip kinderhuiskind kan verwarrend wees, aangesien dit wel 'n kind is wat in 'n kinderhuis woon, maar wat tog ook wees en fatherless is sonder om noodwendig ' $n$ kind te wees van wie die vader en/of moeder nie meer leef nie.

- God se voorkeuropsie vir gemarginaliseerdes: Die frase "preferential option for the poor" is in baie kringe met uiteenlopende kommentare en interpretasies gebruik. "The phrase means different things to different people, and it is questionable whether all of these meanings are obligatory in light of, or even compatible with, the gospel." (Byrne, 1993:212.) Die argument dat "preferential option" 'n onregverdige wegkeer vanaf die rykes is, is nie ter sprake in die ware argument van "preferential option" nie, aangesien God se liefde vir alle mense bedoel is en dat God wil hê dat almal tot geloof moet kom. Ryk en arm word nie teenoor 
mekaar gestel nie. Wat God se liefde en genade betref, is almal ryk en arm - gelyk voor Hom.

Wanneer God egter die toestand en hulpeloosheid van die gemarginaliseerdes raaksien, gaan sy hart na hulle uit en kan daar van ' $n$ "preferential option for the poor" gepraat word. Dit is presies wat Pope (1993:242) sê:

My argument is that the preferential option, properly understood, appeals to an expansion rather than contraction of love and wisdom, and that this form of partiality must not be associated with those forms which encourage a disregard for fairness, a distortion of truth seeking, and a narrowing of the universal love of God.

Die voorkeur van God vir die gemarginaliseerdes is gebaseer op talle Skrifuitsprake soos Psalm 146, Psalm 147 en Jesaja 1:16-17 om net 'n paar te noem. Dit bring ons noodwendig by 'n ondersoek na gemarginaliseerdheid in die Ou Testament.

\subsection{Gemarginaliseerdes in die Ou Testament}

God kom deurlopend in die Ou Testament na vore as 'n God wat besorg is oor die historiese gebeure van die mens se bestaan. Hy is 'n God wat optree en tussenbeide tree om die mens van omstandighede van lyding en onregverdigheid te bevry. Hy is sensitief vir die lyding van mense. Die Hebreeuse chesed word deurlopend gebruik om die guns, barmhartigheid, liefde en ontferming van God vir mense uit te druk.

Die twee sentrale gebeure in die Bybel, naamlik die verhaal van Israel in Eksodus en die lewe en werk van Jesus, laat geen twyfel daaroor dat God 'n besliste opsie uitspreek ten gunste van die gemarginaliseerdes nie. Die uittog van die Israeliete uit Egipte vertel die verhaal van 'n God wat omgee en die verslaafde Israeliete uit die hand van die Egiptenare red. Hierdie verhaal van redding uit slawerny, van groot uitdagings in die woestyn, van geloof en bevryding vorm die grondslag van die oorsprong van die Christelike geloof (Kysar, 1991:12). Hierdie verhaal beeld God uit as 'n God wat honger en dors na geregtigheid; ' $n$ God wat bevry deur sy genade en liefde; 'n God wat verwag dat mense verantwoordelik moet wees vir mekaar (Kysar, 1991:13). Hy sien en hoor die ellende van mense en tree daadwerklik op (Eks. 3:7-10).

In hierdie aksie wat God inisieer om sy volk in nood by te staan, gee Hy aan 'n ander mens - Moses - opdrag om namens Hom hierdie 
bevryding te bewerkstellig (Kysar, 1991:13). Dit is telkens God wat in die Ou Testament daarop aandring dat die individu en sy volk vir mekaar moet sorg en omgee soos wat Hy medelye gehad het met sy volk in Egipte. Sonder medemenslikheid het godsdienstige praktyke vir God weinig betekenis (Jes. 58:6-7). Wanneer die volk van God hulle verantwoordelikheid teenoor die gemarginaliseerdes verontagsaam, tree God telkens teen hulle op (Ps. 72:13; 82:3; Jes. $25: 4$; Amos $4: 1 ; 5: 11 ; 8: 6)$. God verwag dat diegene wat met lewensmiddele geseënd is, hulle verantwoordelikheid moet nakom deur dit te deel met diegene wat nie het nie. Die rykes moet met behulp van hulle bronne en lewensmiddele die situasie van die armes verander. "Thus, the responsibility for initiative lay with the privileged rather than with the dispossessed themselves, even as God had taken the initiative to deliver Israel." (Kysar, 1991:15.)

\subsection{Die werk en lewe van Jesus en die Nuwe Testament}

Wanneer na die lewe en werk van Jesus gekyk word, is die armes/ gemarginaliseerdes dié groep met wie Jesus nie net baie tyd spandeer het nie, maar ook dié groep waarvoor die volgelinge van Jesus verantwoordelikheid moet neem. "Want die armes het julle altyd by julle, maar My het julle nie altyd nie." (Matt. 26:11.)

In Matteus 25 en 26 koppel Jesus die verantwoordelikheid teenoor die gemarginaliseerdes aan 'n lewende verhouding met Homself. In Hoofstuk 25 sê Hy spesifiek dat die barmhartigheid teenoor die gemarginaliseerdes barmhartigheid teenoor Homself is. ' $n$ Afwesigheid van barmhartigheid aan gemarginaliseerdes plaas mense buite die koninkryk van God.

Dit impliseer egter nie dat ons redding van weldade afhang nie:

This does not imply salvation by merit, but rather that a personal relationship with Christ will inevitably produce works of benevolence. Where such works of charity are absent, we may conclude that a personal relationship toward Christ is in fact absent. And without Christ we can never enter into God's Kingdom. (Janse van Rensburg, 2000:46; vgl. ook De Klerk, 1978:22-24; Rom. 12:8.)

Paulus se metafoor van die gemeente as 'n liggaam met baie lede beklemtoon die beginsel van inter-afhanklikheid en gelyke sorg vir mekaar (1 Kor. 12:26; Gal. 6:2). 


\section{Plasing in die kinderhuis}

\subsection{Die effek van die verwydering}

Die verwydering van 'n kind uit die ouerhuis is een van die mees traumatiese ervarings wat 'n kind kan beleef (Van der Merwe, 1998:45; Toerien, 2001:27). Hoe jonger die kind tydens verwydering is, hoe meer traumaties is die ervaring vir die kind, aangesien hy/sy nog nie oor die nodige vaardighede beskik om verbale verklarings vir die verwyderingervarings en trauma te verstaan nie. Dit is ook baie moeilik om die sekuriteitsgevoel wat die jonger kind by sy ouers beleef in 'n kinderhuisopset te hervat (Toerien, 2001:27; Steenberg, 1995:35). Verskeie disfunksionele gesinsomstandighede is dikwels die rede vir die kind se verwydering uit die ouers se sorg en sy/haar opname in 'n kinderhuis (Nicholas et al., 2003:78; Steenberg, 1995:33).

Daar is verskeie faktore tydens die kind se verwydering uit die ouers se sorg wat bepaal hoe die kind op die verwydering gaan reageer. Vir die werk van die pastoor, terapeut en/of die Christen wat by die kinderhuiskind betrokke is, is die volgende feite uiters belangrik:

- Die mate van binding wat daar tussen die betrokke kind en sy/haar ouers bestaan;

- die kind se persepsies en redes vir die verwydering;

- die omstandighede tydens die verwydering;

- die aard van die omgewing waaruit die kind verwyder word; en

- die kind se egosterkte tydens die verwydering en die duur van die verwydering (vgl. Steenberg, 1995:35; Toerien, 2001:27-28).

'n Algemene verskynsel is dat dit dikwels die kinderhuiskind se hartsbegeerte is om na sy ouers terug te gaan, ongeag die redes vir sy/haar verwydering en ongeag die voortdurende negatiewe omstandighede by die ouerhuis. Dit sal vir die pastor/Christen betrokke by 'n kinderhuiskind noodsaaklik wees om deeglik kennis te neem van die kinderhuiskind se voortdurende terughunkering na die omstandighede wat eintlik nadelig was. Hierdie vreemde gedrag kom dikwels voor ten spyte van die kinderhuiskind se negatiewe omstandighede in die gesin en dit lei dikwels tot gedragsprobleme (Herbert, 2002:21; Toerien, 2001:27; Steenberg, 1995:35).

Omdat die kind verward is, word die skuld dadelik op hom-/haarself geneem en die kind ontwikkel 'n negatiewe beeld van hom-/haarself. 
"So anger, guilt, resentment, and self-blame become diffused and mixed up with the child's self-image." (Oaklander, 1988:277; Roberts, 1990:47.) Indien die kind nie die geleentheid kry om sy/haar ervarings van verlies te verwerk nie, kan gevoelens van skuld, blamering, vyandigheid, ontkenning en vrees ontwikkel.

'n Selfblamerende kind het soms self-destruktiewe denke. "If appropriate counselling skills are used, then the child will be able to discard self-destructive beliefs and to replace them with more adaptive beliefs." (Geldard \& Geldard, 1997:50.) 'n Kind wat hom-/haarself blameer en dus skuldig voel en baie onseker en deurmekaar is, is 'n kind wat ook nie weet wat van hom/haar verwag word nie (Oaklander, 1988:277; Carstens \& Fouché, 2004:4; Kleinke, 1998:243).

Aangesien aggressie 'n groot gedragsprobleem by die kinderhuiskind is, moet hierdie moeilik-hanteerbare saak deeglik in ag geneem word. Die kinderhuiskind toon dikwels die neiging om sy/haar woede of vyandigheid aan ander toe te skryf (Bohnert et al., 2003). Die aggressiewe kinderhuiskind beskik gewoonlik oor genoegsame kognitiewe moontlikhede om portuurgroepkonflik te hanteer, maar maak staat op outomatiese opsies wat minder effektief is wanneer hulle onder druk reageer (Beauchaine et al., 2002). Aggressie en antisosiale gedrag in kinders kan egter ook geassosieer word met laer intelligensie (vgl. Carlson, 2003).

Wanneer aggressiewe kinderhuiskinders onder druk verkeer, reageer hullle vinnig op 'n uitlokkende situasie. Ryan en Walker meen dat omtrent alle kinders wat van hulle gesin of ouers verwyder is, glo dat hulle waardeloos is en dat niemand vir hulle lief is nie. "They blame themselves for the actions of adults. If they have been abandoned, neglected or injured by their parents or wider family they are convinced that they brought it upon themselves." (Ryan \& Walker, 1993:6.)

\subsection{Behoeftes van die kind in die kinderhuis}

Die behoeftes van die kinderhuiskind verskil van die kind wat in 'n normale ouerhuis grootword (Paul, 1993:36). Die verlede van die kind wat in die kinderhuis opgeneem word, is kompleks en uniek en daarom is elke kind se behoeftes ook uniek. Die onderstaande lys behoeftes van die kinderhuiskind is nie 'n allesomvattende lys nie, maar vervul eerder die funksie om die werk en rol van die pastoor/Christen te fasiliteer. Indien hierdie behoeftes van die kinderhuiskind egter wel hanteer word, sal dit die aanpassing van die kinderhuiskind in die kinderhuis vergemaklik (Pringle, 1986:34): 'n Lys behoef- 
tes wat in aanmerking geneem moet word in die pastorale ondersteuning, sluit die volgende in:

\section{- Die behoefte aan liefde en sekuriteit}

Die kinderhuiskind het nodig om te voel dat hy/sy behoort en waardeer word (Fouché \& Nieuwoudt, 1991:173). Dit impliseer dat die pastorale hulp nie bloot gewone broederlike liefde impliseer nie. Hier is groter uitdagings om die liefde van Jesus Christus en die sekuriteit wat die kinderhuiskind nodig het, te demonstreer en te voorsien.

\section{- Die behoefte aan nuwe ervarings}

Elke lewensfase het sekere take wat bemeester moet word. Wanneer daar geen geleenthede vir leer is nie, kan geen groei plaasvind nie. Die manifestasie van hierdie groeitake hang nie net af van die kind se aangebore vermoëns nie, maar ook van omgewingsgeleenthede en aanmoediging. Gewoonlik is die gesin van die kinderhuiskind slegs op basiese behoeftebevrediging ingestel. Nuwe ervarings bied aan die kinderhuiskind die potensiaal vir ontwikkeling en die aanleer van vaardighede (Pringle, 1986:53; Van der Berg, 1993:28; Kroon, 1993:60).

\section{- Die behoefte aan verantwoordelikheid}

By die kind wat nie die geleentheid gebied word om verantwoordelikheid te aanvaar nie, ontbreek die vermoë om 'n gevoel van verantwoordelikheid ten opsigte van hom-/haarself, ander en materiële aspekte te ontwikkel. Dit gaan hand aan hand met die gebrek aan beheer oor sy/haar eie lewe en vooruitbeplanning (Pringle, 1986: 103; Kroon, 1993:61; Toerien, 2001:32).

\section{- Die behoefte aan erkenning en om van waarde te wees}

Die kinderhuiskind wat reeds onder soveel ontbering en verwaarlosing gely het, het baie min of selfs geen lof en/of erkenning ontvang nie. 'n Gebrek aan lof en erkenning kan tot 'n gevoel van mislukking, apatie en swak prestasie lei (Steenberg, 1995:44). Dit is dus belangrik dat die kind se goeie hoedanighede deur middel van individualisering beklemtoon word (Roux, 1998:49; Pringle, 1986: 97; Toerien, 2001:33).

\section{- Die behoefte om iewers te behoort en iets te besit}

Elke kind wil graag identifiseer met 'n tuiste - 'n plek waar hy geborge voel. Elke kind behoort sy eie persoonlike besittings, soos 
klere en speelgoed te ontvang (Porter, 1983:80; Toerien, 2001:33; Roux, 1998:49).

\section{- Die reg op individualiteit en 'n eie identiteit}

In identiteitsvorming is dit belangrik om oor kennis betreffende jou agtergrond en spesifiek jou ouers te beskik (Porter, 1983:92). Die kinderhuiskind het 'n sterk behoefte om oor wat gebeur het voor en tydens sy verwydering uit sy ouerhuis te kan praat (Kroon, 1993:63) en om met die verlede vrede te maak (Paul, 1993:39).

\section{Pastorale hulp aan die kinderhuiskind}

Benewens algemene beginsels vir die pastoraat is daar ook bykomende vereistes vir die pastorale versorging van die kinderhuiskind.

\subsection{Pastorale grondhouding}

Volgens Lindijer (1984:108-111) het Rogers op psigiese gebied klem gelê op die terapeut se grondhouding ten einde sukses in die psigoterapeutiese proses te verseker. Rogers was egter nie die eerste persoon om hierdie aspek te beklemtoon nie (vgl. De Klerk, 1978). Die Skrif beklemtoon ook hierdie deugde in die lewe van Jesus, naamlik kongruensie, onvoorwaardelike aanvaarding (agting) en empatiese begrip en meelewing. Hierdie aspekte word vervolgens uit die Skrif beskryf.

\subsubsection{Kongruensie en integriteit}

Hiermee word bedoel heelheid, egtheid, integriteit, konsekwentheid en om jouself te wees (Lindijer, 1984:108). Vir Roberts (1985:269) dui die volgende Nuwe-Testamentiese karaktertrekke op 'n kongruente houding: selfbeheersing, volharding, geduld, standvastigheid en deursettingsvermoë. Vanuit 'n verhoudingsperspektief is hierdie aspek van die pastoor/Christen se grondliggende houding gesetel in die God van die verbond (Eks. 3:14, 15). Janse van Rensburg (2004:296) omskryf die verskillende integriteitsgestaltes as professionele, etiese, arbeids-, vertroulikheids- en geloofsintegriteit. Wanneer die pastoor/Christen hierdie karaktertrekke openbaar, kan die kinderhuiskind vrymoedigheid hê om teenoor hulle oop te maak sonder vrees dat sy/haar vertroue geskend of hy/sy op 'n dwaalspoor gelei sal word. 


\subsubsection{Onvoorwaardelike aanvaarding (agting)}

Hiermee word bedoel dat die gespreksgenoot as persoon aanvaar word sonder enige voorwaardes - dat 'n warme en sorgende houding uitgestraal word wat die kinderhuiskind veilig laat voel. Daar is geen vooroordeel nie. Dit is een van die uitstaande kenmerke van God se verbond met die volk Israel. Die terapeutiese tegniek van onvoorwaardelike aanvaarding staan nie op dieselfde vlak as die agape van Jesus Christus nie. Die eerste word aangeleer, terwyl die laaste uit 'n persoonlike ontmoeting met Christus spruit en uitmond in die pastor se lewe as beeld van God (Roberts, 1985:267-269). Dit skep die geleentheid dat hulle dieselfde gesindheid van liefde wat daar in Jesus was, ook nou na die ander sal uitstraal (Fil. 2:5).

Die hantering van 'n kinderhuiskind met byvoorbeeld fetale alkoholsindroom (FAS) kan moontlik ingewikkeld voorkom, maar indien daar met die nodige agtergrondskennis en veral met die nodige aandag aan die vestiging van 'n vertrouensverhouding gewerk word, kan 'n kinderhuiskind met FAS wel baie goed bygestaan word. Die FAS-kind kan moontlik nie noodwendig die vaardigheid toon om te bepaal hoe individue in verhouding met mekaar staan nie (Grobler, 2003:68; Wait et al., 2003:1).

\subsubsection{Empatiese begrip en meelewing}

Dit impliseer dat die pastor/Christen die belewenis van die kinderhuiskind verstaan. Dit is om basies in die kinderhuiskind se skoene te staan, om jou in sy/haar situasie in te leef. Die pastor/Christen verplaas homself tot binne die verwysingsraamwerk van die kinderhuiskind. Met so 'n houding beleef die kinderhuiskind dat die pastoor/Christen verstaan wat hy/sy beleef en bedoel. Dit stel hoë eise aan die pastor, omdat dit moeilik is om presies te begryp wat die kinderhuiskind dink en ervaar.

Dit sou wel moontlik wees om 'n uitgebreide lys van verdere voorvereistes vir die terapeutiese gesprek aan te gee (Potgieter, 2001: 179-187; De Klerk, 1978:64-85; Venter, 1996:118-125).

\subsection{Vertrouensverhouding}

Vertroulikheid kan beskou word as 'n voorwaarde vir basiese menslikheid (Voigt, 1995:7). Elke persoon het die reg om self te besluit of en watter inligting oor hom bekend gemaak kan word (Janse van Rensburg, 2004:594). Hierin lê die kern van vertroulikheid opgesluit. Die verontagsaming daarvan kan die terapeutiese proses laat skipbreuk ly. Pope en Vasques (1991:36) beskryf dit soos volg: 
Trust is a deeply personal experience that defines the therapistclient relationship and provides a context for a sometimes bewildering ... of hopes, hurts, failures, realizations, vulnerabilities, questions, and possibilities of change that can constitute the processes of psychotherapy.

Die pastor en psigoterapeut staan hier op dieselfde vlak - daarom geld dit ook vir die pastor-kinderhuiskindverhouding.

\subsection{Gesindheid van diens}

Om as net nóg 'n nommer behandel te word, of as net nóg 'n "lastige-kinderhuiskind" hanteer te word, is om die gemarginaliseerde persoon van die pastor te laat wegskram. 'n Gesindheid van diensbaarheid speel dus 'n belangrike rol. Die pastor se dienskneggestalte is gefundeer in Jesus se praktiese demonstrasie van 'n ware dienskneggestalte (Matt. 20:28). Om in 'n diensbaarheidsgestalte beskikbaar te wees, is om die kinderhuiskind se belange voorop te stel en te bevorder in die gees van Christus. In die pastor se dienskneggestalte ervaar die kinderhuiskind by implikasie Christus se diensbaarheid en dit skep vrymoedigheid. Nederigheid en selflose diens bevorder die gespreksverhouding, terwyl selfsugtigheid en selfgenoegsaamheid die verhouding demp.

\section{4 'n Duidelik geformuleerde kommunikasieboodskap}

God se verbondsboodskap word die duidelikste aan die mens gekommunikeer in die vleeswording van Jesus Christus (Hebr. 1:1). Op Pinksterdag (Hand. 2:113) oorbrug die Heilige Gees die kommunikasieprobleem deur middel van die wonder van verskeie tale, sodat almal van die groot dade van God kan verneem. Hiermee verseker die Verbondsgod dat die verbondsboodskap duidelik en ondubbelsinnig na elke volk, taal en nasie sal uitgaan. Op 'n besondere wyse is effektiewe kommunikasie met die kinderhuiskind van groot belang. Hoffman (2002:213-216) vra tereg dat die pastoor/Christen as verbondskommunikator in al die bedieningsfasette effektief sal optree. Hierin bied sy ook 'n verbondswoordeskat aan wat nuttig gebruik kan word. Misverstande in die kommunikasieproses kan ontstaan as gevolg van byvoorbeeld onduidelike taal, onakkurate woordgebruik, vooropgestelde ingesteldhede, onakkurate gevoelsuitdrukking en fisiese gehoorverlies. Dit is die klein jakkalsies wat die wingerd van die pastorale terapie kan verniel. 


\subsection{Luistervaardighede}

Daar is basies twee maniere om na 'n gesprek te luister, naamlik om na die woorde en hulle inhoud te luister, óf om na die emosie agter die woorde te luister. Laasgenoemde geval word "aktiewe luister" genoem. Dit is veral belangrik om in 'n terapeutiese gesprek dieper te luister as na die oppervlakkige woorde (De Klerk, 1978:78). Aktiewe luister is deel van die pastor se empatiese meelewing. Daarmee gee hy te kenne dat hy verstaan wat die kinderhuiskind wil deurgee. In die narratiewe gespreksmodel is dit te bevraagteken in hoeverre aktiewe luister gerig is op die emosie agter die woorde, of op die inhoud van die woorde. Die pastor se suksesvolle aktiewe luister kan die kinderhuiskind laat reageer met "Dis presies wat ek bedoel", of "Presies, jy verstaan". Hierdie reaksie laat die pastoor besef dat hy empaties met die persoon meeleef in die verstaan van hoe die probleem beleef word.

\section{6 'n Samewerking- en onderhandelingstyl}

'n Hermeneutiese benadering is essensieel in die pastorale sorg en terapie (Janse van Rensburg, 2000:2) en geld in die besonder by kinderhuiskinders. Alhoewel 'n hermeneuties intersubjektiewe benadering met 'n postmoderne paradigma in verband gebring kan word (Janse van Rensburg, 2000:11-12), is daar geen rede waarom dit nie ook deel van 'n Skrifgefundeerde benadering kan wees nie (Janse van Rensburg, 2000:2). Omdat die pastoor/Christen gewoonlik nie self gemarginaliseerd is nie, sal ware begrip vir die kinderhuiskind se belewing sonder die kind se insette byna onmoontlik wees. Hiermee word 'n direktiewe benadering (subjek/objek) egter nie uitgesluit nie, veral wanneer met die kinderhuiskind gewerk word. Gegewe die omstandighede en agtergrond van die kinderhuiskind, kan nie verwag word dat hy sonder onderrig en leiding sy weg na ' $n$ bestendige lewe sal vind nie. Daar moet egter gewaak word teen 'n direktiewe benadering wat onsensitief mag voorkom vir die talle probleme wat die kinderhuiskind in sy aanpassing mag ervaar.

\section{9. 'n Beperkte fenomenologiese studie}

\subsection{Metodologie}

'n Fenomenologiese evaluering kan waargeneem en kwalitatief beskryf word, maar nie eksak gemeet word nie (Maher, 2003:1). In 'n beperkte kwalitatiewe ondersoek, wou hierdie navorsing die onbetrokkenheid van Christene in die lewens van kinderhuiskinders on- 
dersoek. In die operasionaliseringsproses is die sleutelkonsepte van die probleemstelling verbind aan die fenomeen wat bestudeer is.

Hierdie verbinding is bewerkstellig deur die daarstelling van ' $n$ vraelys wat as meetinstrument gedien het. Die inhoud van die vraelys is deur die vooropgestelde hipoteses bepaal en in die fokusgroepsituasies gebruik. Items is in die meetinstrument op so 'n manier geformuleer dat die veranderlikes van die studie geoperasionaliseer kon word.

Die teikenpopulasie is gedefinieer as die Afrikaans- en Engelssprekende inwoners van Kleinmond wat op 'n gereelde basis Christengemeentes in Kleinmond besoek en hulself as Christene beskou. Om ewekansigheid en verteenwoordiging in die seleksieproses te probeer verhoog, is ' $n$ proporsioneel-verteenwoordigende en gestratifieerde steekproef gebruik deur Christene uit verskillende gemeentes te selekteer om die fokusgroep te vorm.

\subsection{Gevolgtrekkings vanuit die fenomologiese studie}

Waardevolle en bruikbare inligting het uit die fenomologiese ondersoek na vore gekom. Verskeie leemtes is geïdentifiseer wat direkaanleidende faktore is vir die gebrek aan belangstelling en aktiewe betrokkenheid by die kinderhuiskind. In geen orde van prioriteit nie word die volgende faktore weergegee:

- Daar is geen lering, prediking, Bybelstudie of opleiding aan lidmate gegee nie en ook geen publikasies in gemeentes beskikbaar gestel oor die Christen se verantwoordelikheid om in die lewens van kinderhuiskinders betrokke te wees nie.

- Daar is geen afkondigings oor verwante aangeleenthede in verband met die kinderhuis vanaf preekstoele gemaak wat gemeentelede se belangstelling kon prikkel of lidmate daadwerklik betrokke kon maak nie. Gemeentes is dus nie voorberei om lidmate te onderrig en op te lei om by kinderhuiskinders betrokke te raak nie.

- Slegs enkele individue en die vroue van die barmhartigheidsdiens van gemeentes was by die kinderhuis betrokke en dan slegs in die vorm van skenkings soos klere en kos.

- Alhoewel die hoof van 'n kinderhuis die grootste verantwoordelikheid het om die belange en behoeftes van die kinderhuis in die gemeenskap te behartig en bekend te maak, kon kinderhuise ongelukkig geen inligting of programme bied om dit vir Christene 
moontlik te maak om by kinderhuiskinders betrokke te raak nie. Kinderhuise behoort deur middel van 'n pamflet inligting oor die behoeftes van die betrokke kinderhuis aan alle kerke en die gemeenskap beskikbaar te stel.

\subsection{Gemeentelike betrokkenheid}

'n Bediening bestaan nie net uit 'n bediening van individue nie, maar ook van die gemeente as 'n eenheid. In 'n gemeenskap verbind die verbond in Christus die lidmaat met God en sy medelidmate (Van Pelt, 1999:104, 312). Hendriks (1992:108) beskou die klem wat op die liggaamsmodel gelê word, asook die aanvullende koinoniaverbande en die belang van kleingroepe en diensgroepe as tekenend van hierdie onderlinge versorging in gemeentes.

Die onderlinge sorg in 'n geloofsgemeenskap/gemeente is 'n uiters belangrike aspek van die "praktiese Christenskap" wat heeltemal te min aandag geniet (Maree, 2008:178). Sodanige onderlinge sorg manifesteer gewoonlik in vriendskappe, telefoongesprekke, biduurgroepe en spontane reaksies op krisisse (De Jongh van Arkel, 2000:2). Hierdie soort sorg spruit gewoonlik uit 'n gebondenheid (commitment) wat Christenvriende teenoor mekaar het. In 1 Korintiërs 12 sien die gemeente van Christus om na elke lid wat hulp nodig het. Elke lid van die gemeente van Christus moet omgee en omsien na medelede wat barmhartigheid en hulp nodig het. "En as een lid ly, ly al die lede saam; en as een lid geëer word, is al die lede saam bly" (1 Kor. 12:26). Elke lid van die gemeente van Christus is daarom verantwoordelik om om te sien na die ander (Gal. $6: 2$ ). Die vraag moet nie wees of daar in die lewe van kinderhuiskinders betrokke geraak moet word nie, maar eerder hoe daar in hulle lewens betrokke geraak kan word tot eer van Christus Jesus. Die hulp aan kinderhuiskinders moet deel wees van die lewe van elke Christen en gemeentes wat met hierdie kinders in aanraking kom (Maree, 2008:178). Dit is nodig om die regte praktyke en riglyne te probeer bepaal ten einde van optimale nut vir sulke kinders en terselfdertyd vir die koninkryk van God te wees.

Die opdrag van God aan die gemeente, naamlik "jy moet jou naaste liefhê soos jouself", kan slegs uitgevoer word in dié mate waarin God se wil vir hulle persoonlike lewens geld. 'n Gemeente se vlak van betrokkenheid word kollektief bepaal deur die vlak van betrokkenheid van sy individuele lidmate. Pastorale sorg is vir Venter (1996:62) meer georganiseerd en dit sluit aspekte soos huisbesoek, siekebesoek, rousmartgesprekke en gesinskrisisse in. Hierdie take kan uitgevoer word deur 'n pastor sowel as Christenvrywilligers 
(Venter, 1996:62). Die doel van hierdie sorg is die hantering van die persoonlike en geestelike nood van mense. Lekeberaders wat nie oor dieselfde opleiding as 'n pastor beskik nie, kan dus ook gebruik word om hierdie werk te doen (Roux \& Kotze, 1997:56). Die pastorale gespreksbenadering deur die pastor is net 'n verlengstuk van die geloofsgemeenskap (Louw, 1997:304). Die wedersydse sorg vir mekaar is die konteks waarbinne die pastoraat funksioneer.

Die meeste lidmate is slegs bereid om deur middel van gebed by kinderhuiskinders betrokke te raak, maar nie by die kinders self nie. Aangesien elke lid van die gemeente van Christus moet omgee en omsien na elkeen wat barmhartigheid en hulp nodig het, veral gemarginaliseerdes soos kinderhuiskinders, is dit die verantwoordelikheid van elke lidmaat om aktief betrokke te wees.

Take van barmhartigheid aan kinderhuiskinders kan onder leiding van die pastor en onder toesig van die kerkraad en bestuur van die kinderhuis uitgevoer word. Die hoof van die kinderhuis en personeel moet in alle aktiwiteite geken word. Aangesien persoonlike kontak en belangstelling belangrik is, kan die volgende maniere van betrokkenheid oorweeg word:

- Kinders kan op hulle verjaarsdae met 'n geskenk en gelukwensing verras word.

- Kinders kan vir 'n Sondaguitstappie na 'n dieretuin, museum of piekniek uitgenooi word.

- Materiële behoeftes soos klere, skoene en skoolbenodigdhede kan aangevul word.

- Mense kan oorweeg om 'n polis uit te neem wat vir een of meer kinderhuiskind se opleiding kan voorsien.

- Die gemeente kan deur middel van pamflette, afkondigings, en so meer van die kinderhuis se behoeftes, bedrywighede en beplanning ingelig word.

- Die pastor en lidmate kan betrokke wees deur inligting te verskaf wanneer ' $n$ kind in iemand se sorg geplaas word. Vir die suksesvolle terapeutiese betrokkenheid van die pastoor/Christen by 'n kinderhuiskind moet daar deeglik kennis geneem word van die feit dat daar dikwels 'n negatiewe ingesteldheid bestaan teenoor kinderhuiskinders. Hierdie ingesteldheid is as gevolg van hulle ras, hulle betrokkenheid en gerugte oor hulle betrokkenheid by diefstal en die gebruik van dwelms asook hulle fetale alkohol- 
sindroomstatus. Die feit dat die meeste kinderhuiskinders "bruin" en "swart" kinders is, maak dit vir blanke persone moeiliker om by hulle betrokke te wees. Die vrees dat kinderhuiskinders diefstal sal pleeg as hulle in mense se sorg geplaas word, maak lidmate huiwerig om vir pleegsorg of aanneming aan te meld.

\section{Samevattende gevolgtrekkings}

Die doel van die navorsing was om vas te stel in watter mate lidmate 'n Christelike roeping het om by die kinderhuis en kinderhuiskinders betrokke te wees. Deur 'n Bybelse perspektief is aangetoon dat God 'n besondere sorg vir gemarginaliseerdes openbaar en gelowiges oproep om vir hulle sorg en verantwoordelikheid te aanvaar. Dit blyk egter geen maklike taak te wees nie. Die fenomenologiese ondersoek het aangetoon dat daar talle redes is waarom gelowiges nie betrokke wil wees nie. Talle leemtes is ook blootgelê wat vir die gebrek aan betrokkenheid en belangstelling by die kinderhuis verantwoordelik is. Merkers vir die pastorale sorg van die kinderhuiskind is ook aangetoon. Hier lê 'n groot taak en geleentheid vir die kerk van Jesus Christus om ook vir hierdie gemarginaliseerde kinders van Hom te sorg.

\section{Geraadpleegde bronne}

AMPLIFIED BIBLE. 1978. Michigan: Zondervan.

BABBIE, E. \& MOUTON, J. 2001. The practice of social research. Belmont: Oxford University Press.

BEAUCHAINE, T.P., STRASSBERG, Z., KEES, M.R. \& DRABICK, D.A.G. 2002. Cognitive response repertoires to child noncompliance by mothers of aggressive boys. Journal of abnormal child psychology, Feb. http://www.findarticles.com/p/articles/mi_m0902/is_1_30/ai_84341840 Date of access: 25 Jun. 2007.

BOHNERT, A.M., CRNIC, K.A. \& LIM, K.G. 2003. Emotional competence and aggressive behavior in school-age children. Journal of abnormal child psychology, Feb. http://www.find articles.com/p/articles/mi_m0902/ is_1_31/ai_97891764 Date of access: 16 Dec. 2007.

BYRNE, P.H. 1993. Resentment and the preferential option for the poor. Theological studies, 54(1):213-241.

CARLSON, L.A. 2003. Existential theory: helping school counselors attend to youth at risk for violence. Professional school counseling. http://www.findarticles.com/p/articles/mi_mOKOC/is_5_6/ai_106913865 Date of access: 3 Jun. 2007.

CARSTENS, R.C. \& FOUCHË, A. 2004. Workshop: play techniques in the assessment of sexually abused children, 29 Jul. 2004, Gauteng.

CATTANACH, A. 2003. Introduction to play therapy. London: BrunnerRoutledge.

DE JONGH VAN ARKEL, J.T. 2000. Recent movements in practical theology. Forthcoming. 
DE KLERK, J.J. 1978. Herderkunde. Pretoria: NG Kerkboekhandel.

FOUCHÉ, H.A. \& NIEUWOUDT, J.M. 1991. Selfaktualisering binne die kinderhuis. Maatskaplike werk/Social work, 27(2):165-174.

GELDARD, K. \& GELDARD, D. 1997. Counselling children: a practical introduction. London: Sage.

GROBLER, H.B. 2003. Indigo children: gestalt therapeutic guidelines for parents and caretakers: a Christian perspective. Pretoria: Unisa. (Unpublished M.A. dissertation.)

HENDRIKS, J. 1992. Strategiese beplanning in die gemeente. Wellington: Hugenote Uitgewers.

HERBERT, M. 2002. Social and antisocial development. Oxford: Blackwell.

HOFFMAN, L. 2002. 'n Verbondsgefundeerde paradigma vir die pastorale begeleiding van die egpaar met fertiliteitsuitdagings. UOVS: Bloemfontein. (Ph.D.-proefskrif.)

JANSE VAN RENSBURG, J. 2000. Theology and economics: pastoral care and poverty. Theological forum issue, 28(1 \& 2):158, 167.

JANSE VAN RENSBURG, J. 2004. Pastorale integriteit. Nederduitse Gereformeerde teologiese tydskrif, 45(3 \& 4):586-598.

KLEINKE, C.L. 1998. Coping with life challenges. 2nd ed. Pacific Grove: Brooks/Cole.

KROON, S. 1993. Biblioterapie in die behandeling van die kinderhuiskind. Potchefstroom: PU vir CHO. (Ongepubliseerde M.A.-verhandeling.)

KYSAR, R. 1991. Called to care. Biblical images for social ministry. Augsburg: Fortress.

LINDIJER, C.H. 1984. Pastor en therapeut. 's Gravenhagen: Boekencentrum.

LOUW, D.J. 1997. Diakonaat in skeppingsperspektief: die ekologiese aspek van pastorale sorg. Praktiese teologie in SA, 12(1):52-62.

MAHER, M. 2003. The potential role of spirituality in conducting field research: examination of a model and a process. The qualitative report, 8(1):158.

MAREE, G.J 2008. Pastoraat aan gemarginaliseerdes: 'n Christelike roeping. Bloemfontein: UOVS. (M.A- verhandeling.)

NICHOLAS, B., ROBERTS, S. \& WURR, C. 2003. Looked after children in residential homes. Child and adolescent mental health, 8(2):78-83.

OAKLANDER, V. 1988. Windows to our children. New York: Gestalt Journal.

PAUL, R. 1993. Herkomsinterpretasie met 'n wetsbestede kind deur middel van die aanwending van spelterapie. Pretoria: Universiteit van Pretoria. (Ongepubliseerde M.A.(MW)-miniverhandeling.)

POPE, K.S. \& VASQUES, M.J.T. 1991. Ethics in psychotherapy and counseling. Oxford: Jersey Bass.

POPE, S.J. 1993. Proper and improper partiality and the preferential option for the poor. Theological studies, 64(1):242-271.

PORTER, C. 1983. Terapie met die sorgbehoewende kind. Pretoria: Universiteit van Pretoria. (M.A.-verhandeling.)

POTGIETER, A.V. 2001. Die pastorale gesprek as koinonioterapeutiese bediening. Bloemfontein: UOVS. (M.Th-skripsie.)

PRINGLE, M.K. 1986. The needs of children. 3rd ed. London: Hutchinson.

ROBERTS, J.I. 1990. The feelings of emotionally abused children. Maatskaplike werk/Social work, 26(1):33-45.

ROBBERTS, R.C. 1985. Carl Rogers and the Christian virtues. Journal of psychiatry and theology, 13(4):263-273. 
ROUX, A. 1998. Handleiding van kortkursus in maatskaplike werk: kindersorg. Potchefstroom: $\mathrm{PU}$ vir $\mathrm{CHO}$.

ROUX, J.P. \& KOTZÉ, D.J. 1997. Die koinonale konstruksie van 'n toerustingsprogram vir narratiewe pastorale sorg. Acta theologia, 17(1):126.

RYAN, T. \& WALKER, R. 1993. Life story work. London: British agencies for adoption and fostering.

SCHURINK, E.M., SCHURINK, W.J. \& POGGENPOEL, M. 1998. Focus group interviewing and audio-visual methodology in qualitative research. (In De Vos, A.S., ed. Research at Grass Roots. Pretoria: Van Schaik. p. 193.)

STANFORD ENCYCLOPEDIA OF PHILOSOPHY. 2003. Phenomenology. http://plato.stanford.edu. Date of access: 3 Jun. 2007.

STEENBERG, E. 1995. Die effek van 'n kreatiewe kunsterapeutiese program op die psigologiese funksionering van kinderhuiskinders. Potchefstroom: PU vir CHO. (Ph.D.-proefskrif.)

SUID-AFRIKA. 1983. Wet op Kindersorg, Wet 74 van 1983. Pretoria: Staatsdrukker.

TOERIEN, M. 2001. Die benutting van gestaltspelterapie op die aanpassing van die middelkinderjarige-kind in 'n kinderhuis. Pretoria: Universiteit van Pretoria. (M.A.-verhandeling.)

VAN DER BERG, A.M. 1993. Die effek van 'n kreatiwiteitsprogram op enkele persoonlikheidsaspekte van milieugestremde kinders. Potchefstroom: PU vir CHO. (Ongepubliseerde D.Phil.-proefskrif.)

VAN DER LITH, H.C. 1999. Die hantering van aggressie by die middelkinderjarige kinderhuiskind deur middel van spelterapeutiese groepwerk. Pretoria: Universiteit van Pretoria. (Ongepubliseerde M.A.(MW) (spelterapie)-miniverhandeling.)

VAN DER MERWE, M. 2002. Die invloed van karate op die sosia-emosionele funksionering van die adolessent in die kinderhuis. Pretoria: Universiteit van Pretoria. (Ongepubliseerde M.A.(MW) (spelterapie)-miniverhandeling.)

VAN DER MERWE, M.C. 1998. Die invloed van interpersoonlike verhoudings op die kind in die kinderhuis - 'n maatskaplike werk perspektief. Pretoria: Universiteit van Pretoria. (M.A.-verhandeling.)

VAN PELT, J.W. 1999. Pastoraat in trinitarisch perspektief. Heerenveen: Uitgeverij Groen.

VENTER, C. 1996. Uitkringende liefdesbetoon: RGN-studies in praktiese teologie. Pretoria: RGN.

VOIGT, C.M. 1995. Die hantering van vertroulike inligting in hulpverlenende professies: 'n vergelykende studie. Bloemfontein: UOVS. (M.Soc.Scskripsie.)

WAIT, J.W.V., MEYER, J.C. \& LOXTON, H.C. 2003. Lecture notes in development. Cape Town: Ebony Books.

\section{Kernbegrippe:}

Bybelse beginsels

gemarginaliseerd

kinderhuiskinders

terapeutiese riglyne

\section{Key concepts:}

Biblical principles

children's home children

marginalised

therapeutical guidelines 


\section{Adendum A}

\section{Hoofareas van die fokusgroepvrae}

In hierdie studie is die volgende vrae direk aan die fokusgroepdeelnemers gestel met die doel om die navorsingsvrae verder te ontsluit:

\section{Gemeentelike bydrae}

Indien die Christen nie inligting ontvang oor sy goddelike verpligting om betrokke te wees in die lewens van kinderhuiskinders in sy gemeenskap nie, sal dit vir die Christen as enkeling moeiliker wees om betrokke te wees en daarom is die volgende vrae wel relevant:

- Watter lering word daar in die gemeente oor die Christen se betrokkenheid by kinderhuiskinders gegee?

Moontlike opvolgvrae om gesprekke te stimuleer:

- Wat is die kernboodskap wat uit preke kom aangaande die Christen se betrokkenheid by kinderhuiskinders?

- Watter inligting/skoling word aan kinders en tieners oor hulle betrokkenheid by kinderhuiskinders gegee?

- Watter kennis en inligting word oor hierdie onderwerp in die vorm van publikasies soos gemeenteblaaie, ensovoorts verskaf?

- Watter Bybelstudies word oor hierdie onderwerp aangebied?

- Wat kan die Christen as individu doen om die situasie te verbeter?

- Wat kan die plaaslike gemeentes doen om die situasie te verbeter?

\section{Inligting en programme vanaf die kinderhuis}

- Watter soort inligting word deur die kinderhuis verskaf oor hoe 'n persoon of gemeente betrokke kan wees by kinderhuiskinders?

Moontlike opvolgvrae om gesprekke te stimuleer:

- Hoe bereik hierdie inligting van die kinderhuis die gemeenskap?

- Watter programme/geleenthede word deur die kinderhuis aan die gemeenskap beskikbaar gestel om by kinderhuiskinders betrokke te wees? 
- Wat kan die kinderhuis doen om die situasie te verbeter?

\section{Ingesteldhede teenoor kinderhuiskinders}

- Watter rol speel ras, intellektuele vermoëns, fetale alkoholsindroomstatus, antisosiale gedrag, negatiewe gerugte, ensovoorts van kinderhuiskinders dat daar 'n negatiewe ingesteldheid teenoor kinderhuiskinders bestaan?

Moontlike opvolgvrae om gesprekke te stimuleer:

- Veroorsaak negatiewe verhale en ervarings met kinderhuiskinders dat die Christen liewer nie betrokke wil wees in die lewens van kinderhuiskinders nie? Indien ja, brei uit.

- Wat kan die kinderhuis doen om die situasie te verbeter?

\section{Direkte kontak met 'n kinderhuiskind}

- Voel $u$ in die verleentheid om met 'n kinderhuiskind geassosieer te word? Indien ja, brei uit.

Moontlike opvolgvrae om gesprekke te stimuleer:

- Het $u$ die nodige kennis hoe om 'n kinderhuiskind te hanteer? Brei uit.

- Voel u huiwerig om persoonlik betrokke te raak by 'n kinderhuiskind as gevolg van moontlike gedragsprobleme wat die kinderhuiskind kan openbaar? Brei uit.

- Is die inligting wat die kinderhuis aan die gemeenskap bied genoegsaam om u huiwerigheid op te klaar?

- Wat kan die kinderhuis doen om die situasie te verbeter.

\section{Geestelike betrokkenheid}

Is u op 'n geestelike vlak betrokke by 'n kinderhuiskind?

Moontlike opvolgvrae om gesprekke te stimuleer:

- Weet u hoe om iemand wat God nie ken nie, na Jesus Christus te lei?

- Weet $u$ hoe om 'n kinderhuiskind by te staan en te help met sy/haar geestelike vrae en groei?

- Wat kan die Christen as individu doen om hierdie situasie te verbeter? 
- Wat kan die plaaslike gemeentes doen om hierdie situasie te verbeter? 
